ISSN 1818-1295 elSSN 2616-6194

REPORTS OF MORPHOLOGY
$\begin{gathered}\text { Official Journal of the Scientific Society of Anatomists, } \\ \text { Histologists, Embryologists and Topographic Anatomists } \\ \text { of Ukraine } \\ \text { journal homepage: https://morphology-journal.com }\end{gathered}$

\title{
Modeling of sonographic parameters of the kidneys in practically healthy women of the middle intermediate somatotype depending on the constitutional parameters of the body
}

Cherkasov V.G. ${ }^{1}$, Ustymenko O.S. ${ }^{1}$, Shayuk A.V. ${ }^{2}$, Prokopenko S.V. ${ }^{3}$, Gunas I.V. ${ }^{3}$

${ }^{1}$ Bogomolets National Medical University, Kyiv, Ukraine;

2Zhytomyr Ivan Franko State University, Zhytomyr, Ukraine;

${ }^{3}$ National Pirogov Memorial Medical University, Vinnytsya, Ukraine

\section{ARTICLE INFO}

Received: 11 July, 2018

Accepted: 31 July, 2018

UDC: $616-073.4-8: 616.61: 616-$ 055.1:616-055.2

\section{CORRESPONDING AUTHOR}

e-mail: iryna.tymoshenko@i.ua Cherkasov V. G.
The scientific literature presents quite a large number of works, in which the priority role of mathematical modeling in providing high-quality medical care, health and active longevity of a person is determined. The purpose of the work is to construct and analyze the regression models of individual sonographic sizes of kidneys in practically healthy women of the middle intermediate somatotype, depending on the features of the anthropometric and somatotypological indicators. Within the framework of the agreement on scientific cooperation from the database of National Pirogov Memorial Medical University, Vinnytsya primary sonographic parameters (length, width, anterior-posterior dimension, area of longitudinal and cross-section of the kidneys and their sinuses, as well as volume of the right and left kidneys) and anthropometric indices (obtained by the method of V.V. Bunak in the modification of P.P. Shaparenko) of 17 practically healthy women of the first mature age of the middle intermediate somatotype, who in the third generation live in the Podillya region of Ukraine. The construction of regression models of individual sonographic sizes of the kidneys, depending on the features of anthropo-somatotypological parameters of the body of women of the middle intermediate somatotype, was carried out in the licensed package "Statistica 6.1". In women of the middle intermediate somatotype all 16 possible reliable regression models of sonographic parameters of the kidneys were constructed depending on the anthroposomatotypological parameters with the determination coefficient $R^{2}$ from 0.891 to 0.978 . The analysis of reliable regression models (with a coefficient of determination greater than 0.6), the sonographic parameters of the kidneys in practically healthy women of the middle intermediate somatotype revealed that most often models of both kidneys, as well as separately of the right and left kidneys, include the circumferential dimensions of the body (respectively, 35.9 - 33.3 - 38.5\% of the total number of indicators included in the models). In addition, models of both kidneys most often include cephalometric indices (12.6\%), thickness of skin-fat folds and body diameters (by $11.7 \%$ ); models of the right kidney - body diameters (15.7\%), cephalometric indices and width of distal epiphyses of long tubular bones of extremities (by 11.8\%); models of the right kidney - the thickness of skin and fat folds (17.3\%) and cephalometric indices (13.5\%). Attention is drawn to the lack of entry into models of sonographic sizes of kidneys total body sizes.

Keywords: regression analysis, sonographic parameters of the kidneys, indicators of body structure and body sizes, practically healthy women, middle intermediate somatotype.

\section{Introduction}

Huge factual material collected during the century of observation by practicing doctors and enriched with modern hardware researches of the kidneys, requires careful attention of specialists in the field of mathematical forecasting $[11,13,19]$. A fairly large number of works in which the fundamental scientific component comes to the fore, defining in the future the priority role of mathematical modeling in providing high-quality health care, health and 
active longevity of man [20, 29].

For today, sufficiently effective approaches have been developed to quantitatively model the various properties of the kidneys [21, 29]. Let's consider only one very important aspect of scientific research concerning the problem of predicting the size of the kidneys, since their increase or decrease serves as an important indicator of renal and extrarenal disorders [2, 14, 22]. Moreover, mathematical prediction of their size may be one of the most affordable tools for testing effectiveness and the possibility of implementing such new ideas as the use of miniature endoscopic camera designed for diagnostic studies and minimally invasive surgical interventions unattainable for traditional technologies [5]. Such studies are carried out on the basis of regression equations with the reproduction of real parameters of the kidneys, which are matched with experimental and sectional data [6].

The basis for mathematical modeling is proved association of parameters of kidneys with features of a structure of a human body [7, 10-12]. The results of a number of scientific studies indicate the possibility of situations where a significant reduction or increase in one or several parameters of physical development correlates with the corresponding dimensional variations of the organ $[8,9,18$, 21, 23].

Thus, mathematical modeling, in direct conjunction with the revolution in the field of instrumental and diagnostic equipment, can provide penetration to fundamentally new levels of understanding of medical and biological processes $[17,20,21,24]$.

The purpose of the work is to construct and analyze the regression models of individual sonographic sizes of kidneys in practically healthy women of the middle intermediate somatotype, depending on the features of the anthropometric and somatotypological indicators.

\section{Materials and methods}

Within the framework of the agreement on scientific cooperation between the Department of Human Anatomy of the Bogomolets National Medical University, Kyiv and the research center of the National Pirogov Memorial Medical University, Vinnytsya from the database of the latter taken the primary sonographic parameters and anthropometric indices of practically healthy men and women of the first mature age, who in the third generation live in the Podillia region of Ukraine.

With the help of the ultrasound diagnostic system "CAPASEE" SSA-220A (Toshiba, Japan), a convective sensor with a working frequency of $3.75 \mathrm{MHz}$ and a diagnostic ultrasound system Voluson 730 Pro (Austria), a convective sensor of 4-10 MHz, a sonographic study of kidneys was performed [16], which included determination of length, width, anterior-posterior size, longitudinal and cross-sectional area of the kidneys and their sinuses. According to the generally accepted formula: $\mathrm{V}=0.524 \times \mathrm{L} \times \mathrm{W} \times \mathrm{AP}$, where, $\mathrm{V}$ is the volume of the kidney, $L$ is the length of the kidney, $W$ is the width of the kidney, S - the anterior-posterior size of the kidney, the volume of the right and left kidneys is counted.

Anthropometric survey was conducted by V. V. Bunak method in the modification of P.P. Shaparenko [25]; estimation of the somatotype - according to the mathematical scheme J. Carter and B. Heath [3]; indicators of the body composition (fat, bone and muscle) according to the formulas of J. Matiegka [15], as well as the muscular component of the body mass according to the formulas of the American Institute of Nutrition [26].

The construction of regression models of individual sonographic sizes of the kidneys, depending on the features of anthropo-somatotypological parameters of the body of women of the middle intermediate somatotype, was carried out in the licensed package "Statistica 6.1". In the direct stepwise regression analysis, we determined the following conditions: the final version of the model should have a determination coefficient $\left(R^{2}\right)$ of at least 0.60 , the F-criterion value of not less than 3.0, and the number of free members included in the model must be minimal.

\section{Results}

In practically healthy women of the middle intermediate somatotype $(n=17)$, the following reliable models of sonographic parameters of the kidneys were constructed depending on the features of the anthropometric and somatotypological parameters:

RE_R_DL (length of the right kidney in the longitudinal section, $\mathrm{mm})=70.73+1.423 \times \mathrm{ACR}+3.573 \times$ OBPL1 $1.377 \times$ ATP $-1.467 \times \mathrm{OBPR}_{1}-7.351 \times \mathrm{EPPR}+3.694 \times \mathrm{EPG}$ $+1.539 \times \mathrm{OBPR}_{2}\left(\mathrm{R}^{2}=0.976 ; \mathrm{F}_{(7.9)}=51.33 ; \mathrm{p}<0.001 ;\right.$ St. Error of estimate $=1.322$ ),

where (here and thereafter), $\mathrm{R}^{2}$ - determination factor; $F_{(! ! ! !)}=$!!!!! - critical (!.!!) and received (!!!!!) values of Fisher's criterion; St. Error of estimate - standard error of standardized regression coefficient; ACR - shoulder width $(\mathrm{cm})$; OBPL1 - shoulder girth in a tense state $(\mathrm{cm})$; ATP is the height of the finger point $(\mathrm{cm}) \mathrm{OBPR}_{1}$ - the forearm circumference in the upper third $(\mathrm{cm})$; EPPR - the width of the distal epiphysis of the forearm $(\mathrm{cm})$; EPG - width of the distal epiphysis of the shin $(\mathrm{cm}) ; \mathrm{OBPR}_{2}$ - the forearm's girth in the lower third $(\mathrm{cm})$.

RE_L_DL (the length of the left kidney in the longitudinal section, $\mathrm{mm}$ ) $=117.5+1.484 \times \mathrm{ACR}+20.70 \times \mathrm{EPPL}-10.66$ x OBPR $2-10.23$ x LX -3.364 x GGR + 0.974 x CRIS $\left(R^{2}=0.953 ; F_{(6.10)}=33.51 ; p<0.001 ;\right.$ St. Error of estimate $=$ 2.640),

where (here and thereafter), EPPL - the width of the distal epiphysis of the shoulder (cm); LX - ectomorphic component of somatotype for Heath-Carter (score); GGR thickness of skin and fat folds on the chest $(\mathrm{mm})$; CRIS interspinous pelvis size $(\mathrm{cm})$. 
RE_R_PO (width of the right kidney in the longitudinal section, $\mathrm{mm})=111.4-4.885 \times \mathrm{OBPR}_{2}+0.843 \times \mathrm{OBT}-0.821$ $x$ ATP + $3.707 \times$ EPPL $-0.619 \times$ SAG_DUG + $0.226 \times$ GB $\left(R^{2}=0.961 ; \quad F_{(6.10)}=40.82 ; p<0.001 ;\right.$ St. Error of estimate $=0.978)$,

where (here and in the future), OBT - waist circumference (cm); SAG_DUG - sagittal arch of the head (cm);

RE_L_PO (width of the left kidney in the longitudinal section, $\mathrm{mm})=163.8-6.903 \times \mathrm{OBPR}_{2}+3.116 \times$ GPR -2.387 $x$ GGR -4.649 x LX+1.685 x OBK - $0.995 \times \mathrm{OBPL}_{2}\left(\mathrm{R}^{2}=0.891\right.$; $F_{(6.10)}=13.60 ; p<0.001$; St. Error of estimate=2.205),

where (here and thereafter), GPR - thickness of skin and fat folds on the forearm (mm); OBK - hands brush circumference $(\mathrm{cm}) ; \mathrm{OBPL}_{2}$ - shoulder girth in a calm condition $(\mathrm{cm})$;

RE_R_TO (anterior-posterior size of the right kidney on a cross-section, $\mathrm{mm})=61.13+2.221 \times \mathrm{ATL}-3.017 \times \mathrm{OBG}_{2}$ - $2.673 \times$ B_SH_GL - $6.882 \times$ LX $-2.126 \times$ SGK $-0.478 \times$ GB $-0.644 \times$ OBB $\left(R^{2}=0.969 ; F_{(7.9)}=40.47 ; p<0.001\right.$; St. Error of estimate $=1.255)$,

where (here and in the future), ATL - height of the pubic point $(\mathrm{cm}) ; \mathrm{OBG}_{2}$ - girth of the shin in the lower third $(\mathrm{cm})$; B_SH_GL - maximum head width $(\mathrm{cm})$; SGK - anteriorposterior size of the chest $(\mathrm{cm})$; GB - thickness of skin-fat fold on the side $(\mathrm{mm})$; OBB - hip circumference $(\mathrm{cm})$;

RE_L_TO (anterior-posterior size of the left kidney on the cross-section, $\mathrm{mm}$ ) $=60.79-3.693 \times \mathrm{OBPR}_{2}+0.954 \mathrm{x}$ ATL $-0.496 \times \mathrm{GB}+0.442 \times \mathrm{GPR}-0.881 \times \mathrm{OBG}_{1}+0.458 \times \mathrm{GL}$ $-0.544 \times$ B_DL_GL $\left(R^{2}=0.957 ; F_{(7.9)}=28.49 ; p<0.001\right.$; St. Error of estimate $=1.008$ ),

where (here and thereafter), $\mathrm{OBG}_{1}$ - girth of the shin in the upper third $(\mathrm{cm}) ; \mathrm{GL}$ - thickness of skin and fat folds under the shoulder blade (mm); B_DL_GL - the largest length of the head $(\mathrm{cm})$;

RE_R1SRE (area of the longitudinal section of the right kidney, $\left.\mathrm{cm}^{2}\right)=-115.9+4.521 \times \mathrm{OBPL}_{2}-1.195 \times \mathrm{ATP}-1.646$ x MM + $3.460 \times$ OB_GL $-6.465 \times$ EPPL - $0.695 \times$ B_DL_GL + $2.284 \times \operatorname{EPG}\left(R^{2}=0.972 ; F_{(7.9)}=45.31 ; p<0.001\right.$; St. Error of estimate $=0.861$ ),

where (here and thereafter), MM - muscle component of the body mass, by Matiegka (kg); OB_GL - head girth (cm);

RE_R2SRE (square cross-section of the right kidney, $\left.\mathrm{cm}^{2}\right)=\overline{7} .650-0.734 \times \mathrm{ACR}+0.599 \times \mathrm{PSG}-4.236 \times \mathrm{OBPR}_{2}$ $+0.403 \times$ OBT $+1.727 \times$ OBK $+0.335 \times$ ATV $\left(R^{2}=0.926\right.$; $F_{(6.10)}=20.82 ; p<0.001$; St. Error of estimate $\left.=1.273\right)$, where (here and thereafter), PSG - transverse middlethoracic size $(\mathrm{cm})$; ATV - height of the trochanteric point $(\mathrm{cm})$;

RE_L1SRE (area of the longitudinal section of the left kidney, $\left.\mathrm{cm}^{2}\right)=135.1+2.595 \times$ GPPL $-6.421 \times \mathrm{LX}-6.239 \mathrm{x}$ $\mathrm{OBPR}_{2}-3.284 \times \mathrm{GGR}+3.672 \times \mathrm{OM}-1.315 \times \mathrm{ACR}+0.820 \mathrm{x}$ OBB $\left(R^{2}=0.942 ; F_{(7.9)}=20.85 ; p<0.001 ;\right.$ St. Error of estimate $=1.867$ ),

where (here and thereafter), GPPL - the thickness of the skin-fat fold on the front surface of the shoulder $(\mathrm{mm})$; $\mathrm{OM}$ - bone component of body weight by Matiegka $(\mathrm{kg})$;

RE_L2SRE (square cross-section of the left kidney, $\mathrm{cm}^{2}$ ) $=-18.93+0.358 \times$ ATL $-2.898 \times \mathrm{OBPR}_{2}+1.332 \times \mathrm{OBK}-$ $0.281 \times \mathrm{OBGK}_{2}+0.930 \times \mathrm{SH}$ LLICA $+0.667 \times$ OB_GL $\left(R^{2}=0.938 ; F_{(6.10)}=25.11 ; p<0.001\right.$; St. Error of estimate $=0.727$ ),

where (here and in the future), $\mathrm{OBGK}_{2}$ - the girth of the chest on the exhalation $(\mathrm{cm})$; SH_LICA - face width $(\mathrm{cm})$;

RE_R1SSI (area of the longitudinal section of the sinus of the right kidney, $\left.\mathrm{cm}^{2}\right)=11.95-3.243 \times \mathrm{OBPR}_{2}+5.816 \mathrm{x}$ $\mathrm{EPPL}+0.307 \times \mathrm{OBT}-0.352 \times \mathrm{OBG}_{1}+0.334 \times \mathrm{ACR}-1.101$ $x$ FX $\left(R^{2}=0.895 ; F_{(6.10)}=14.14 ; p<0.001 ;\right.$ St. Error of estimate $=0.919$ ),

where (here and in the future), FX is the endomorphic component of the somatotype by Heath-Carter (score);

RE_R2SSI (square cross section of the sinus of the right kidney, $\left.\mathrm{cm}^{2}\right)=987.6-55.04 \times$ CRIS + 76.44 x PSG - 33.31 x $P N G+28.05 \times$ OBK - 28.21 x SGK - $72.22 \times$ LX $\left(R^{2}=0.918\right.$; $F_{(6.10)}=18.74 ; p<0.001 ;$ St. Error of estimate=48.31),

where (here and thereafter), PNG - transverse lowerthoracic size $(\mathrm{cm})$;

RE_L1SSI (area of longitudinal section of the sinus of the left kidney, $\left.\mathrm{cm}^{2}\right)=0.366+4.079 \times \mathrm{OM}+0.667 \mathrm{x}$ B_SH_GL - $1.248 \times \mathrm{OBPR}_{2}-2.225 \times \mathrm{SH}$ LICA $+0.221 \times \mathrm{GG}$ $+1.537 \times$ SH_N_CH $\left(R^{2}=0.961 ; F_{(6.10)}=40.53 ; p<0.001 ;\right.$ St. Error of estimate $=0.684$ ),

where (here and thereafter), GG - thickness of skin and fat folds on the abdomen (mm); $\mathrm{SH} N \mathrm{~N}$ CH - width of the lower jaw (cm);

RE_L2SSI (square cross-section of the sinus of the left kidney, $\left.\mathrm{cm}^{2}\right)=-4003+69.22 \times$ ATPL $-99.40 \times \mathrm{OBPR}_{2}+$ $18.02 \times \mathrm{OBS}+201.6 \times \mathrm{EPPL}-45.20 \times \mathrm{OBPL}_{1}-34.52 \times \mathrm{ATL}$ - $17.54 \times$ OBB $\left(R^{2}=0.978 ; F_{(7.9)}=56.39 ; p<0.001\right.$; St. Error of estimate=18.46), 
where (here and in the future), ATPL - height of the shoulder point $(\mathrm{cm})$; OBS - foot girth $(\mathrm{cm})$;

RE_R_VRE (volume of the right kidney, $\left.\mathrm{cm}^{3}\right)=-304.3-$ $16.98 \times \mathrm{OBPR}_{2}+9.919 \times \mathrm{GPPL}+14.78 \times \mathrm{OB} \_\mathrm{GL}-27.17 \times$ OM - $6.252 \times$ N_SH_GL + $1.191 \times \mathrm{OBGK}_{1}\left(\mathrm{R}^{2}=0.966\right.$; $F_{(6.10)}=47.55 ; p<0.001 ;$ St. Error of estimate $\left.=5.548\right)$,

where (here and in the future), N_SH_GL - the smallest width of the head $(\mathrm{cm})$; OBGK $\mathrm{OB}_{1}$ - girth of the chest on the inspiration $(\mathrm{cm})$;

RE_L_VRE (volume of the left kidney, $\left.\mathrm{cm}^{3}\right)=-53.17$ $32.56 \times \mathrm{OBPR}_{2}+4.207 \times \mathrm{OBBB}+3.148 \times \mathrm{ATV}+5.879 \times \mathrm{OBS}$ $-7.411 \times$ SH_LICA + 7.072 x SGK - 4.605 x OBSH $\left(R^{2}=0.934\right.$; $F_{(7.9)}=18.19 ; p<0.001 ;$ St. Error of estimate=8.429).

where, OBBB - hips girth $(\mathrm{cm})$; OBSH - neck circumference $(\mathrm{cm})$.

\section{Discussion}

The problems associated with an adequate description of the dimensional characteristics of the kidneys in individuals with different somatotypes are still open for research. Let's start from the fact that the values of the model parameters should be determined as basal, that is, they correspond to the normal state of a healthy organism. The "weak place" of these models may also be that the calculation of the sizes in most works is based on the introduction of a small number of constitutional parameters (height, weight and surface area of the body) into a model based on averaged anthropometric measurements without taking into account the ethnic and age factors [1, 5, 21, 23].

In practically healthy women of the middle intermediate somatotype all 16 possible reliable regression models of sonographic parameters of the right and left kidneys, based on the anthropometric and somatotypological parameters with determination coefficient $R^{2}$ from 0.891 to 0.978 (for right kidney $R^{2}$ from 0.895 to 0.976 , for left kidney $R^{2}$ from 0.891 to 0.978 ) were constructed.

The constructed regression models of sonographic parameters of both kidneys in practically healthy women of the middle intermediate somatotype most often include the circumferential dimensions of the body $(35.9 \%$ of the total number of indicators included in the models), cephalometric indices $(12.6 \%)$, thickness of skin and fat folds and body diameters (by 11.7\%). Among the individual anthropometric and somatotypological indicators, models most often include the forearm circumcision in the lower third (up to 13 models), the width of the distal epiphysis, the shoulder width and the ectomorphic component of the somatotype (up to 5 models), the height of the pubic point and the hands brush circumference (up to 4 models).

The regression models of sonographic parameters of the right kidney in women of the middle intermediate somatotype most often include the circumferential dimensions of the body (33.3\% of the total number of indices included in the right kidney models), body diameters (15.7\%), and cephalometric indices and width of distal epiphyses of long tubular limb bones (by 11.8\%). Among the individual anthropo-somatotypological parameters of the body models of the right kidney most often include the forearm girth in the lower third (up to 5 models), the height of the finger point, the width of the distal epiphysis of the shoulder, the waist circumference and the shoulder width (up to 3 models).

The regression models of the sonographic parameters of the left kidney in women of the middle intermediate somatotype most often include the circumferential dimensions of the body $(38.5 \%$ of the total number of indicators included in the models of the left kidney), the thickness of skin and fat folds $(17.3 \%)$ and cephalometric indices (13.5\%). Among the individual anthroposomatotypological parameters of the body models of the left kidney most often include the circumference of the forearm in the lower third (up to 8 models), the width of the face, the height of the pubic point, the thickness of the skin-fat fold on the chest and the magnitude of the ectomorphic component of the somatotype, according to Heath-Carter (up to 3 models).

Attention is drawn to the lack of entry into models of sonographic sizes of the kidneys in women of the middle intermediate somatotype of total body sizes.

In previous studies $[4,27,28]$ we determined that from 16 possible sonographic parameters of the kidneys, based on the anthropometric and somatotypological indices in practically healthy women of the mesomorphic somatotype, 7 reliable models with a determination coefficient from 0.607 to 0.641 were constructed; in women of ectomorphic somatotype - all 16 models with a determination coefficient from 0.607 to 0.973 ; in women endo-mesomorphic somatotype - 14 models with a determination coefficient from 0.672 to 0.912 . The most frequently constructed models included: women with mesomorphic somatotype circumferential body dimensions $(29.8 \%)$ and cephalometric indexes (19.1\%); in women with ectomorphic somatotype body diameters $(24.2 \%)$, body girth sizes $(20.9 \%)$, cephalometric indices (19.8\%) and thickness of skin and fat folds $(14.3 \%)$; in women of the endo-mesomorphic somatotype, the cephalometric indexes (to the right kidney $24.2 \%$, to the left kidney $15.6 \%$ ), body diameters (to the right kidney $24.2 \%$, to the left kidney $17.8 \%$ ) and the circumferential body size (to the right kidney $24.2 \%$, to left kidney $22.2 \%$ ), and also only to the left kidney thickness of skin and fat folds (17.8\%).

The construction of the regression equations of the kidneys sizes according to the constitutional parameters of a healthy organism becomes rapid and is considered to be an exceptional tool for the study of biomedical problems.

\section{Conclusions}

1. In practically healthy women of the middle intermediate somatotype of 16 possible sonographic parameters of the 
right and left kidneys, depending on the anthropometric and somatotypological parameters, all 16 valid models with a determination coefficient from 0.895 to 0.976 and from 0.891 to 0.978 , respectively, were constructed.

2. Constructed models in women of the middle intermediate somatotype most often include: for the right

\section{References}

[1]Arooj, A., Lam, J., Wui, Y. J., \& Supriyanto, E. (2011). Comparison of Renal Size among Different Ethnicities. International Journal of Biology and Biomedical Engineering, 5(4), 221-229.

[2] Bakker, H., Kooijman, M. N., van der Heijden, A. J., Hofman, A., Franco, O. H., Taal, H. R., \& Jaddoe, V. W. (2014). Kidney size and function in a multi-ethnic population-based cohort of schoolage children. Pediatr. Nephrol., 29(9), 1589-1598. doi: 10.1007/ s00467-014-2793-8

[3] Carter, J. L., \& Heath, B. H. (1990). Somatotyping - development and applications. Cambridge University Press.

[4] Cherkasov, V. G., \& Ustymenko, O. S. (2017). Modeling using regression analysis of sonographic parameters of kidneys depending on the features of the size of practical healthy women with mesomorphic somatotype. World of Medicine and Biology, 3(61), 73-76. doi: 10.26724/2079-8334-2017-3-61-73-76

[5] Correas, J.-M., Anglicheau, D., Joly, D., Gennisson, J.-L., Tanter, M., \& Helenon, O. (2016). Ultrasound-based imaging methods of the kidney-recent developments. Official J. of Int. Society of Nephrology, 90(6), 1199-1210. doi: 10.1016/j.kint.2016.06.042

[6] Draper, N., \& Smith, G. (2016). Applied Regression Analysis. M.: Williams.

[7] El-Reshaid, W., \& Abdul-Fattah, H. (2014). Sonographic assessment of renal size in healthy adults. Med. Princ. Pract., 23(5), 432-436. doi: 10.1159/000364876

[8] Gunas I. V., Kovalenko, D. A., Fomina, L. V., Belik, N. V., \& Fedonyuk, L. Ya. (2010). Modeling, using regression analysis, sonographic parameters of the kidneys, depending on the anthropometric and somatotypological parameters of men and women of the first mature age. Reports of Morphology, 16(4), 915-920.

[9] Harmse, W. S. (2011). Normal variance in renal size in relation to body habitus. South African Journal of Radiology, 15(4), 123126. https//doi.org/10.4102/sajr.v15i4.355

[10] Hyun, Y. Y., Lee, K. B., Rhee, E. J., Park, C. Y., Chang, Y., \& Ryu, S. (2016). Chronic kidney disease and high eGFR according to body composition phenotype in adults with normal BMI. Nutr. Metab. Cardiovasc., 26(12), 1088-1095. doi: 10.1016/ j.numecd.2016.09.003

[11] Jaroszynski, A., Dereziński, T., Jaroszyńska, A., Zapolski, T., Wasikowska, B., Wysokiński, A., ... Horoch, A. (2016). Association of anthropometric measures of obesity and chronic kidney disease in elderly women. Ann. Agric. Environ. Med., 23(4), 636-640. doi: 10.5604/12321966.1226859

[12] Jovanović, D., Gasic, B., Pavlovic, S., \& Naumovic, R. (2013). Correlation of kidney size with kidney function and anthropometric parameters in healthy subjects and patients with chronic kidney diseases. Ren. Fail., 35(6), 896-900. doi: 10.3109/0886022X.2013.794683

[13] Kolchanova, N. A., Goncharova, S. S., Lihovshaya, V. A., \& Ivanisenko, V. A. (2008). System Computer Biology. Novosibirsk: Publishing SORAS.

[14] Maaji, S. M., Daniel, O., \& Adamu, B. (2015). Sonographic measurement of renal dimensions of adults in North western Nigeria: a preliminary report. Sub-Saharan African journal of kidney - the circumferential body dimensions (33.3\%), body diameters $(15.7 \%)$, cephalometric indices and width of distal epiphyses of long tubular bones of the extremities (by $11.8 \%$ ); for the left kidney - the circumferential dimensions of the body (38.5\%), the thickness of skin and fat folds (17.3\%) and cephalometric indices (13.5\%).

medicine, 2(3), 123-127. doi: 10.4103/2384-5147.164420

[15] Matiegka, J. (1921). The testing of physical effeciecy. Amer. J. Phys. Antropol., 2(3), 25-38. https://doi.org/10.1002/ ajpa.1330040302

[16] Mitkov, V. V. (2006). A practical guide to ultrasound diagnostics. General ultrasound diagnosis. M.: Vidar.

[17] Niyyar, V. D., \& O'Neill W. C. (2018). Point-of-care ultrasound in the practice of nephrology. Kidney Int., 93(5), 1052-1059. doi: 10.1016/j.kint.2017.11.032

[18] Okur, A., Serin, H. I., Zengin, K., Erkoc, M. F., Tanik, S., Yildirim, U., ... Akyol, L. (2014). Relationship between kidney volume and body indexes in the Turkish population determined using ultrasonography. Int. Braz. J. Urol., 40(6), 816-822. doi: 10.1590/ S1677-5538.IBJU.2014.06.13

[19] Oparin, O. A., Lavrova, N. V., Blahoveshchenska, A. V., \& Korenovskuy, I. P. (2010). Clinical and ultrasound parallel diagnostics of diseases of internal organs. Tutorial. Recommended by the Ministry of Education and Science of Ukraine. Kharkiv: Fact.

[20] Petrov, V. I., \& Nedogoda, S. V. (2009). Evidence-based medicine: study guide. M.: "GOETAR-MED".

[21] Quaia, E., Nocentini, A., \& Torelli, L. (2009). Assessment of a new mathematical model for the computation of numerical parameters related to renal cortical blood flow and fractional blood volume by contrast-enhanced ultrasound. Ultrasound Med. Biol., 35(4), 616627. doi: 10.1016/j.ultrasmedbio.2008.10.003

[22] Raza, M., Hameed, A., \& Khan, M. I. (2011). Ultrasonographic assessment of renal size and its correlation with body mass index in adults without known renal disease. J. Ayub. Med. Coll. Abbottabad., 23(3), 64-68.

[23] Saeed, Z., Mirza, W, Sayani, R., Sheikh, A., Yazdani, I., \& Hussain, S. A. (2012). Sonographic Measurement of Renal Dimensions in Adults and its Correlates. International Journal of Collaborative Research on Internal Medicine \& Public Health, 4(9), 1626-1641.

[24] Salsberg, E., Quigley, L., Masselink, L., Wu, X., \& Collins, A. (2015). The US Nephrology Workforce 2015: Developments and Trends. Washington, American Society of Nephrology.

[25] Shaparenko, P. P. (2000). Anthropometry. Vinnytsya: [w. p.].

[26] Shephard, R. J. (1991). Body composition in biological anthropology. Cambridge.

[27] Ustymenko, O. S. (2018). Regression models of sonographic parameters of the kidneys in practically healthy women of the ectomorphic somatotype depending on the peculiarities of body size. Biomedical and Biosocial Anthropology, 31, 53-58. doi: 10.31393/bba31-2018-07

[28] Ustymenko, O. S. (2018). Sonographic model parameters of kidney in men and women endo-mesomorphic somatotype depending on the anthropometric indices characteristics. Biomedical and Biosocial Anthropology, 30, 43-49. doi: 10.31393/bba30-2018-06

[29] Voropaeva, O. F., \& Shokin, Yu. I. (2012). Numerical simulation in medicine: Some problem statements and calculation results. Computational Technologies, 17(4), 29-55. 


\section{МОДЕЛЮВАННЯ СОНОГРАФІЧНИХ ПАРАМЕТРІВ НИРОК У ПРАКТИЧНО ЗДОРОВИХ ЖІНОК СЕРЕДНЬОГО ПРОМІЖНОГО СОМАТОТИПУ В ЗАЛЕЖНОСТІ ВІД КОНСТИТУЦІОНАЛЬНИХ ПАРАМЕТРІВ ТІЛА \\ Черкасов В. Г., Устименко О. С., Шаюк А. В., Прокопенко С. В., Гунас І. В.}

В науковій літературі представлено досить велике число робіт, в яких визначається пріоритетна роль математичного моделювання в забезпеченні високоефективного медичного обслуговування, здоров'я та активного довголіття людини. Мета роботи - у практично здорових жінок середнього проміжного соматотипу побудувати та провести аналіз регресійних моделей індивідуальних сонографрічних розмірів нирок в залежності від особливостей антропометричних $i$ соматотипологічних показників. У рамках договору про наукове співробітництво із бази даних Вінницького національного медичного університету ім. М.І. Пирогова взяті первинні сонографрічні параметри (довжина, ширина, передньо-задній розмір, площа поздовжнього та поперечного перерізу нирок та їх синусів, а також об'єм правої і лівої нирок) $і$ антропометричні показники (отримані за методикою В.В. Бунака у модифрікації П.П. Шапаренка) 17 практично здорових жінок першого зрілого віку середнього проміжного соматотипу, які у третьому поколінні проживають на території Подільського регіону України. Побудова регресійних моделей індивідуальних сонографрічних розмірів нирок в залежності від особливостей антропосоматотипологічних параметрів тіла жінок середнього проміжного соматотипу проведена в ліцензійному пакеті "Statistica 6.1". У жінок середнього проміжного соматотипу побудовані усі 16 можливих достовірних регресійних моделей сонографрічних параметрів нирок в залежності від антропо-соматотипологічних показників із коефіцієнтом детермінації $R^{2}$ від 0,891 до 0,978. При аналізі достовірних регресійних моделей (з коефіцієнтом детермінації більшим 0,6) сонографрічних параметрів нирок у практично здорових жінок середнього проміжного соматотипу встановлено, що найчастіше до моделей обох нирок, а також окремо правої і лівої нирок, входять обхватні розміри тіла (відповідно 35,9 - 33,3 - 38,5\% від загальної кількості показників, що входять до моделей). Крім того, до моделей обох нирок найчастіше входять кефралометричні показники (12,6\%), товщина шкірно-жирових складок і діаметри тіла (по 11,7\%); до моделей правої нирки - діаметри тіла (15,7\%) та кефралометричні показники й ширина дистальних епіфізів довгих трубчастих кісток кінцівок (по 11,8\%); до моделей правої нирки - товщина шкірно-жирових складок (17,3\%) та кефралометричні показники (13,5\%). Привертає увагу відсутність входження до моделей сонографрічних розмірів нирок тотальних розмірів тіла.

Ключові слова: регресійний аналіз, сонографрічні параметри нирок, показники будови та розмірів тіла, практично здорові жінки, середній проміжний соматотип.

\section{МОДЕЛИРОВАНИЕ СОНОГРАФИЧЕСКИХ ПАРАМЕТРОВ ПОЧЕК У ПРАКТИЧЕСКИ ЗДОРОВЫХ ЖЕНЩИН СРЕДНЕГО ПРОМЕЖУТОЧНОГО СОМАТОТИПА В ЗАВИСИМОСТИ ОТ КОНСТИТУЦИОНАЛЬНЫХ ПАРАМЕТРОВ ТЕЛА Черкасов В. Г., Устименко Е. С., Шаюк А. В., Прокопенко С. В., Гунас И. В.}

В научной литературе представлено достаточно большое число работ, в которых определяется приоритетная роль математического моделирования в обеспечении высокоэфррективного медицинского обслуживания, здоровья и активного долголетия человека. Цель работы - у практически здоровых женщин среднего промежуточного соматотипа построить и провести анализ регрессионных моделей индивидуальных сонографических размеров почек в зависимости от особенностей антропометрических и соматотипологических показателей. В рамках договора о научном сотрудничестве из базы данных Винницкого национального медицинского университета им. Н.И. Пирогова взяты первичные сонографические параметры (длина, ширина, передне-задний размер, площадь продольного и поперечного сечения почек и их синусов, а также объем правой и левой почек) и антропометрические показатели (получены по методике В.В. Бунака в модификации П.Ф. Шапаренко) 17 практически здоровых женщин первого зрелого возраста среднего промежуточного соматотипа, которые в третьем поколении проживают на территории Подольского региона Украины. Построение регрессионных моделей индивидуальных сонографических размеров почек в зависимости от особенностей антропо-соматотипологических параметров тела женщин среднего промежуточного соматотипа проведено в лицензионном пакете "Statistica 6.1". У женщин среднего промежуточного соматотипа построены все 16 возможных достоверных регрессионных моделей сонографических параметров почек в зависимости от антропо-соматотипологических показателей с коэффициентом детерминации $R^{2}$ om 0,891 до 0,978. При анализе достоверных регрессионных моделей (с коэфффициентом детерминации большим 0,6) сонографических параметров почек у практически здоровых женщин среднего промежуточного соматотипа установлено, что чаще всего к моделям обеих почек, а также отдельно правой и левой почек, входят обхватные размеры тела (соответственно 35,9 - 33,3 - 38,5\% от общего количества показателей, входящих в модели). Кроме того, в модели обеих почек чаще всего входят кефралометрические показатели (12,6\%), толщина кожно-жировых складок и диаметры тела (по 11,7\%); в модели правой почки - диаметры тела (15,7\%), кефалометрические показатели и ширина дистальных эпифизов длинных трубчатых костей конечностей (по 11,8\%); в модели правой почки - толщина кожно-жировых складок (17,3\%) и кефралометрические показатели (13,5\%). Привлекает внимание отсутствие вхождения в модели сонографических размеров почек тотальных размеров тела.

Ключевые слова: регрессионный анализ, сонографические параметры почек, показатели строения и размеров тела, практически здоровые женщины, средний промежуточный соматотип. 